\title{
ChemComm
}

\section{Rationale for the sluggish oxidative addition of aryl halides to $\mathrm{Au}(\mathrm{I}) \dagger$}

Cite this: Chem. Commun., 2014 50, 1533

Received 21st November 2013, Accepted 4th December 2013

DOI: $10.1039 / c 3 c c 48914 k$

www.rsc.org/chemcomm

\author{
Madeleine Livendahl, ${ }^{a}$ Charles Goehry, ${ }^{a}$ Feliu Maseras ${ }^{* a b}$ and \\ Antonio M. Echavarren ${ }^{\star a c}$
}

The oxidative addition of $\mathrm{C}_{\mathrm{sp}^{2}}-\mathrm{Br}$ or $\mathrm{C}_{\mathrm{sp}^{2}}-\mathrm{I}$ bonds to gold(l) does not take place even under very favorable intramolecular conditions that could form five- or six-membered gold(III) metallacycles. DFT calculations reveal that although this process could be feasible thermodynamically, it is kinetically very sluggish.

Gold(I) complexes activate unsaturated substrates in catalytic processes that are characterized by the invariance of the oxidation state of the metal. ${ }^{1}$ Although it was proposed that the Sonogashira $^{2-5}$ and Suzuki coupling could be catalysed by gold, ${ }^{6,7}$ it seems now clear that at least in some cases the catalytic role is played by either small amounts of palladium contaminants $^{8,9}$ or by gold nanoparticles, ${ }^{10-14}$ which probably mediate these couplings by mechanisms very different from those occurring under homogeneous conditions. ${ }^{15,16}$

Organogold(I) complexes transmetallate with $\mathrm{Pd}(\mathrm{II})$, which has been used in their coupling with aryl iodides with palladium catalysts. ${ }^{17-19}$ However, the oxidative addition of aryl halide ArX to a gold(I) complex [AuXL], a necessary step for a cross-coupling catalysed by this type of $\mathrm{d}^{10}$ complexes is unprecedented. Indeed, an alkenyl gold(I) complex with a pending aryl iodide has been structurally characterized as a stable complex, although it could have undergone intramolecular oxidative addition through a sixmembered transition state. ${ }^{20}$ Complexes $\left[\mathrm{AuMePR}_{3}\right]$ behave as ordinary $\mathrm{S}_{\mathrm{N}} 2$ nucleophiles upon adding slowly with alkyl iodides, following the expected order of reactivity: $\mathrm{CH}_{3} \mathrm{I}>\mathrm{EtI}>$ i-PrI. ${ }^{21-23}$ Disulphides undergo oxidative addition reactions with gold(I) dithiolate complexes. ${ }^{24}$ Interestingly, the oxidative addition of a relatively weak $\mathrm{Si}-\mathrm{Si}$ bond to gold(I) is a very favourable

\footnotetext{
${ }^{a}$ Institute of Chemical Research of Catalonia (ICIQ), Av. Països Catalans 16, 43007 Tarragona, Spain.E-mail: aechavarren@iciq.es

${ }^{b}$ Departament de Química, Universitat Autonoma de Barcelona, 08193 Bellaterra, Spain

${ }^{c}$ Departament de Química Analitica i Química Orgànica, Universitat Rovira $i$ Virgili, C/Marcel-li Domingo s/n, 43007 Tarragona, Spain

$\dagger$ Electronic supplementary information (ESI) available. CCDC 891201-891204 and 964933. For ESI and crystallographic data in CIF or other electronic format see DOI: $10.1039 / \mathrm{c} 3 \mathrm{cc} 48914 \mathrm{k}$
}

process. $^{25}$ DFT calculations show that the oxidative addition of iodobenzene to complex $\left[\mathrm{AuI}\left(\mathrm{PMe}_{3}\right)\right]$ has a high activation barrier (31.6 kcal mol${ }^{-1}$ in potential energy, likely higher in free energy). ${ }^{10 a}$ However, bisphosphine gold clusters $\left[\mathrm{Au}_{3} \mathrm{~L}_{5}\right]^{+}$and $\left[\mathrm{Au}_{3} \mathrm{~L}_{6}\right]^{+}$react in the gas phase by $\mathrm{C}-\mathrm{I}$ bond activation. ${ }^{26}$

We decided to study the oxidative addition of $\mathrm{Ar}-\mathrm{X}$ bonds to [AuXL] by examining systems of type $\mathbf{I}$ in which the metal coordinates the phosphorous ligand of a phosphine or phosphite bearing an ortho-halogenated aryl group (Scheme 1). Under these very favourable conditions, the oxidative addition could occur intramolecularly to form gold(III) metallacycles of type II. We have performed DFT calculations to clarify the origin of the sluggishness, thermodynamic or kinetic, of the oxidative addition of aryl halides to gold(I) complexes.

Reaction of phosphites $\left(o-\mathrm{IC}_{6} \mathrm{H}_{4} \mathrm{O}\right)_{3} \mathrm{P}(\mathbf{1 a})$ and $\left(o-\mathrm{IC}_{6} \mathrm{H}_{4} \mathrm{CH}_{2} \mathrm{O}\right)_{3} \mathrm{P}$ (1b) with $[\mathrm{AuCl}(\mathrm{THT})]$ (THT = tetrahydrothiophene) in $\mathrm{CH}_{2} \mathrm{Cl}_{2}$ led to complexes $2 \mathbf{a}(17 \%)$ and $\mathbf{2 b}(10 \%)$ as white solids. Their structures were determined using single crystal X-ray diffraction (Fig. 1 and 2). ${ }^{27}$ These complexes show non- $C_{3}$-symmetrical structures in the solid state with the phosphite ligands adopting a syn-

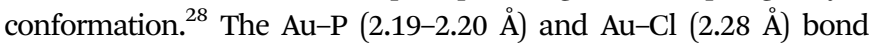
distances are similar in both complexes. In the case of complex 1a, two of the $o$-iodophenyl rings have the $\mathrm{C}-\mathrm{I}$ bonds pointing towards the $\mathrm{Au}(\mathrm{I})$ centre, with a closest $\mathrm{C}_{\mathrm{sp}^{2}}-\mathrm{Au}$ distance of $3.795 \AA$ (Fig. 1a). In contrast, in complex $\mathbf{2 b}$ the $\mathrm{C}-\mathrm{I}$ bonds of the three aryl rings are anti-oriented with respect to the $\mathrm{P}-\mathrm{Au}-\mathrm{Cl}$ bond (Fig. 1b).

The related phosphine complex 4a was obtained in $60 \%$ yield by reacting $\left(o-\mathrm{BrC}_{6} \mathrm{H}_{3}\right)_{3} \mathrm{P}(3)$ with $[\mathrm{AuCl}(\mathrm{THT})]$ in a $1: 1$

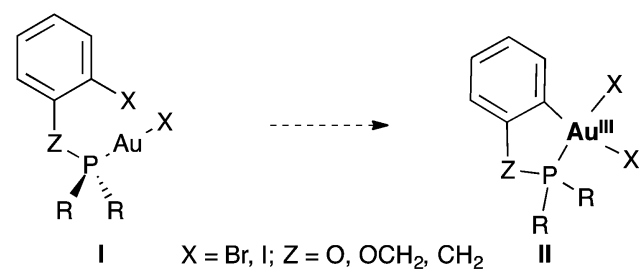

Scheme 1 Hypothetical intramolecular oxidative addition of $\mathrm{C}_{\mathrm{sp}^{2}}-\mathrm{X}$ bonds to $\mathrm{Au}(\mathrm{I})$ to form $\mathrm{Au}($ (II) metallacycles II. 
(a)

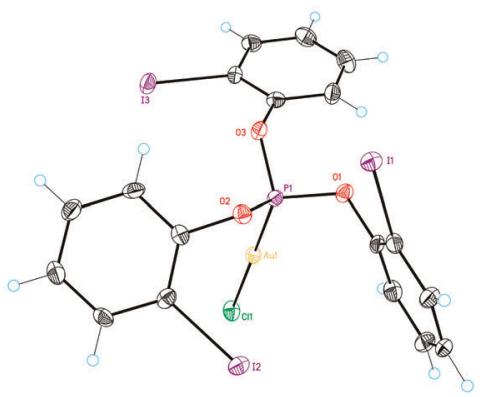

(b)

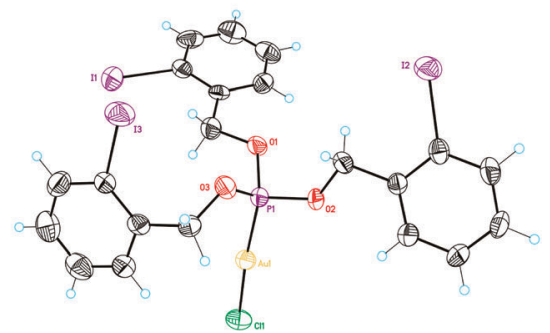

Fig. 1 ORTEP plot (50\% thermal ellipsoids) of the crystal structure of complex $\mathbf{2 a}(\mathrm{a})$ and $\mathbf{2 b}(\mathrm{b})$.

(a)

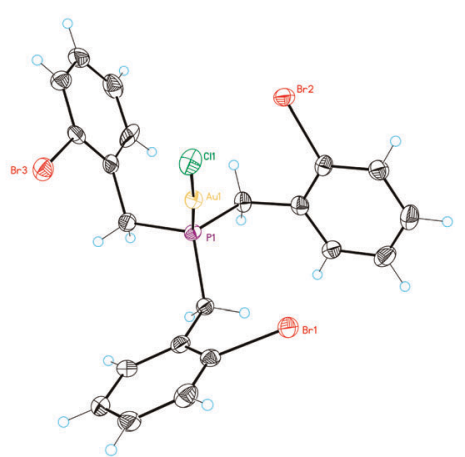

(b)

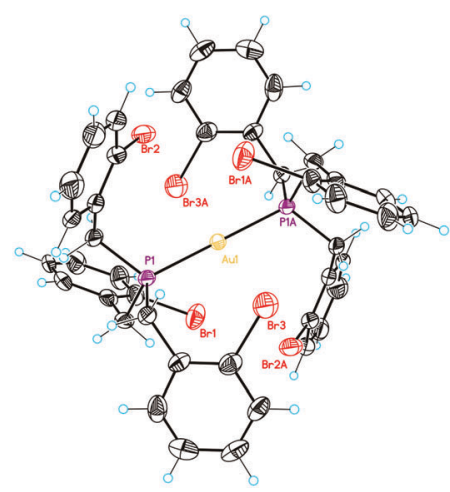

Fig. 2 ORTEP plot (50\% thermal ellipsoids) of the crystal structure of complexes $\mathbf{4 a}$ (a) and $\mathbf{5}$ (b).

ratio. When the reaction was carried out in a $2: 1$ ligand to $\mathrm{Au}(\mathrm{I})$ ratio, bisphosphine gold(I) complex 5 was isolated in $70 \%$ yield. The structures of $\mathbf{4 a}$ and $\mathbf{5}$ were confirmed by X-ray diffraction (Fig. 2). ${ }^{27}$ The Au-P distance in $4 a(2.22 \AA)$ is much shorter than those in more crowded complex 5 (2.30 ̊). Complex 4 a displays an almost $C_{3}$-symmetrical structure with $\mathrm{C}_{\mathrm{sp}^{2}}(\mathrm{Br})-\mathrm{Au}$ distances between 3.61 and $3.86 \AA$ A. We also prepared an analogous complex 4b from (2-bromobenzyl)diphenylphosphine. ${ }^{29}$ Complex 5 shows a $D_{3 \mathrm{~d}^{-}}$-symmmetrical structure with $\mathrm{C}_{\mathrm{sp}^{2}}(\mathrm{Br})-\mathrm{Au}$ distances of $4.1 \AA$ and the six $\mathrm{Br}$ atoms in a non-octahedral arrangement around the metal centre (Br-Au distances of 3.7-3.8 $\mathrm{A})$.

Complexes $\mathbf{2 a}$ and $\mathbf{2 b}$ did not undergo oxidative addition to form the corresponding metallacycles of type II in $\mathrm{CD}_{2} \mathrm{Cl}_{2}$ solution. Similarly, more robust complex 4 was recovered unchanged after being heated in toluene solution at $60{ }^{\circ} \mathrm{C}$ for several days. Furthermore, bisphosphine gold(I) complex 5 failed to form any gold(III) metallacycle after being heated in DMSO at $100{ }^{\circ} \mathrm{C}$ for more than 5 days and was fully recovered without any sign of decomposition.

In order to better understand the reasons for the sluggish reactivity towards oxidative addition of this set of $\mathrm{Au}(\mathrm{I})$ complexes, we carried out computational studies (DFT calculations at the M06 level including solvation effects, values reported in text are free energies). ${ }^{30}$ The relative energies of all transition states and products are collected in Table 1 . A representative transition state, 2t1ts, is shown in Fig. 3. There is simultaneous formation of the $\mathrm{Au}-\mathrm{C}$ and $\mathrm{Au}-\mathrm{Br}$ bonds, with distances of 2.273 and $2.587 \AA$, respectively. It is thus a concerted transition state that leads to complex $\left[\mathrm{PhAuClBr}\left(\mathrm{PMe}_{3}\right)\right]$ with the phosphine cis to $\mathrm{Ph}$, in contrast to that reported from the oxidative addition of $\mathrm{PhI}$ to $\left[\mathrm{Au}\left(\mathrm{PMe}_{3}\right) \mathrm{I}\right]$, which leads to trans-[ $\left.\mathrm{PhAuI}_{2}\left(\mathrm{PMe}_{3}\right)\right]{ }^{10 a}$ The alternative $\mathrm{S}_{\mathrm{N}}$ 2-like transition states $^{31}$ with the initial departure of a bromide anion were also located in a number of cases but had always higher energies than the concerted ones. The endergonic character of the oxidative addition processes computed in Table 1 is consistent with the facile reductive elimination of $\mathrm{R}-\mathrm{R}$ from trialkyl $\left[\mathrm{R}_{3} \mathrm{AuL}\right]$ complexes. ${ }^{32}$

The X-ray structure of $\mathbf{4}$ was used a starting point in the geometry optimization of 1tr to avoid time-consuming conformational searches, ${ }^{33}$ and the same conformation was used in the calculations for $\mathbf{1 t t s}$ and 1tp. The associated transition state 1tts (Fig. 3) has

Table 1 Computed M06 relative energies $\left(\mathrm{kcal} \mathrm{mol}^{-1}\right)$ of transition states and products for oxidative addition

\begin{tabular}{|c|c|c|c|c|c|c|}
\hline & \multicolumn{3}{|c|}{ Transition state } & \multicolumn{3}{|c|}{ Product } \\
\hline & $\mathrm{PMe}_{3}$ & $\mathrm{PPh}_{3}$ & Other & $\mathrm{PMe}_{3}$ & $\mathrm{PPh}_{3}$ & Other \\
\hline 1t & - & - & 41.5 & - & - & 17.4 \\
\hline $2 t$ & 42.6 & 43.0 & - & 17.5 & 23.3 & - \\
\hline $3 t$ & 47.3 & 46.8 & - & 4.1 & 6.5 & - \\
\hline $4 t$ & 48.5 & 45.3 & - & 5.1 & 7.5 & - \\
\hline $5 t$ & - & - & 11.7 & - & - & 4.5 \\
\hline \multirow[t]{7}{*}{$6 t$} & 23.3 & 21.6 & - & 12.1 & 12.7 & - \\
\hline & & & \multicolumn{2}{|c|}{$\mathrm{R}_{3} \mathrm{P}-\mathrm{Au}-\mathrm{Cl}$} & \multicolumn{2}{|c|}{$\mathrm{Ph}_{3} \mathrm{P}-\mathrm{Au}-\mathrm{Me}$} \\
\hline & \multirow{2}{*}{\multicolumn{2}{|c|}{$1 \operatorname{tr}=4$}} & \multicolumn{2}{|c|}{$\begin{array}{l}2 \operatorname{t1r}(\mathrm{R}=\mathrm{Me}) \\
2 \operatorname{t2} r(\mathrm{R}=\mathrm{Ph})\end{array}$} & \multicolumn{2}{|c|}{$\begin{array}{l}3 t 1 r(R=M e) \\
3 \operatorname{tar}(R=P h)\end{array}$} \\
\hline & & & \multicolumn{2}{|c|}{$\mathrm{Ph} \stackrel{+}{-} \mathrm{Br}$} & \multicolumn{2}{|c|}{$\stackrel{+}{\mathrm{Ph}-\mathrm{Br}}$} \\
\hline & \multicolumn{2}{|c|}{$\mathrm{R}_{3} \mathrm{P}-\mathrm{Au}-\mathrm{H}$} & \multicolumn{2}{|c|}{$\mathrm{Au}-\mathrm{Cl}$} & \multicolumn{2}{|c|}{$\mathrm{R}_{3} \mathrm{P}-\mathrm{Au}^{+}$} \\
\hline & \multicolumn{2}{|c|}{$\begin{array}{l}4 \operatorname{t1r}(\mathrm{R}=\mathrm{Me}) \\
4 \operatorname{t2r}(\mathrm{R}=\mathrm{Ph})\end{array}$} & \multicolumn{2}{|c|}{5 tr } & \multicolumn{2}{|c|}{$\begin{array}{l}\text { 6t1r }(\mathrm{R}=\mathrm{Me}) \\
6 \mathrm{t} 2 \mathrm{r}(\mathrm{R}=\mathrm{Ph})\end{array}$} \\
\hline & \multicolumn{2}{|c|}{+} & \multicolumn{2}{|c|}{+} & \multicolumn{2}{|c|}{$\stackrel{+}{\mathrm{Ph}-\mathrm{Br}}$} \\
\hline
\end{tabular}



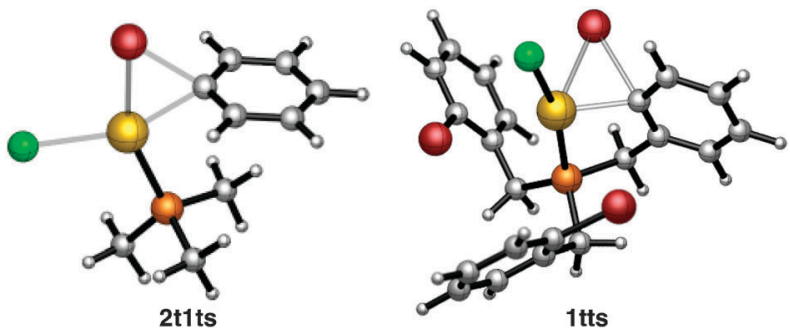

Fig. 3 M06 optimized structure of transition states $\mathbf{2 t 1}$ ts and $\mathbf{1}$ tts colour codes: red $=\mathrm{Br}$, purple $=\mathrm{P}$, yellow $=\mathrm{Au}$, green $=\mathrm{Cl}$.

a relative free energy of $41.5 \mathrm{kcal} \mathrm{mol}^{-1}$ above the reactant. This is in full agreement with the lack of reactivity under the experimental conditions. The relative free energy of intermediate 1tp, which is only $17.4 \mathrm{kcal} \mathrm{mol}^{-1}$ higher than the starting Au(I) complex 1tr, could be accommodated into a catalytic cycle, but not that of the transition state. This hints at a kinetic rather than thermodynamic origin for the lack of reactivity of $\mathrm{Au}(\mathrm{I})$ complexes in oxidative addition processes.

Further calculations showed that the more electron depleted the aryl halide was rendered, the lower the barrier for the oxidative addition became. ${ }^{30}$ However, even in the most favourable case, 2,4,6-trinitro-bromobenzene, the activation energy is still relatively high $\left(28.0 \mathrm{kcal} \mathrm{mol}^{-1}\right) .{ }^{30}$

We also analysed the origin of this high barrier. One possible reason could be the strain associated with the fact that the intramolecular oxidative addition process leads to the trans arrangement of phenyl and bromide in the product. The geometrical arrangement in 1tts with the C-Br bond "above" gold, instead of the more usual in-plane arrangement must have some energy penalty. To clarify its importance we carried out additional calculations for the intermolecular reaction on systems $2 \mathbf{t} 1,2 \mathbf{t} 2,3 \mathbf{t} 1,3 \mathbf{t} 2$, $\mathbf{4 t 1}$, 4t2, (Table 1) where the oxidatively added $\mathrm{C}-\mathrm{Br}$ bond is in a bromobenzene unit not previously connected to the metal. A variety of systems were considered that differed in the nature of the phosphine $\left(\mathrm{PMe}_{3}\right.$ or $\left.\mathrm{PPh}_{3}\right)$ and of the spectator ligand (chloride, methyl or hydride). The free energy barriers for these intermolecular processes, leading to a cis arrangement of phenyl and bromide, were in a narrow span between $42.6 \mathrm{kcal} \mathrm{mol}^{-1}$ (for 2t1ts) and $48.5 \mathrm{kcal} \mathrm{mol}^{-1}$, (for 4t1ts). These barriers are also close to the $41.5 \mathrm{kcal} \mathrm{mol}^{-1}$ computed for $1 \mathrm{tts}$. This means that the cost associated with the trans nature of 1t1ts is nearly identical to the entropic penalty for bringing two separate molecules together. In any case, these results mean that the high barrier for the oxidative addition to $\mathrm{Au}(\mathrm{I})$ reflects an intrinsic reluctance to undergo oxidative reaction in these systems. It must be mentioned that there is a much wider dispersion in the relative energies of oxidative addition products, from $4.1 \mathrm{kcal} \mathrm{mol}^{-1}$ for $3 \mathrm{t} 1 \mathrm{p}$ to $23.3 \mathrm{kcal} \mathrm{mol}^{-1}$ for $2 \mathrm{t} 2 \mathrm{p}$. This seems to be related to different combinations of trans influences in the computed systems. It is however important to remark that although in some cases the reaction is too endergonic to take place, this is not the general behaviour. The high kinetic barrier is on the other hand present in all tested systems.

A possible origin for the high barrier in systems 1 to $4 \mathbf{t}$ is the well-known strong preference of Au(I) complexes for a linear 2-coordination, ${ }^{34}$ which is challenged by the simultaneous formation of two new bonds at the transition state. We tested this hypothesis through additional calculations on systems $5 \mathbf{t}$, 6t1, and 6t2 (Table 1). The resulting barriers were 11.7, 23.3 and $21.6 \mathrm{kcal} \mathrm{mol}^{-1}$, respectively. It is clear that the reaction becomes much easier when starting from a mono-coordinated $\mathrm{Au}(\mathrm{I})$ complex, thus providing evidence in favour of our hypothesis that coordination number is the key.

Our joint experimental and computational study demonstrates that linear 2-coordinate $\mathrm{d}^{10} \mathrm{Au}(\mathrm{I})$ complexes are much less reactive towards oxidative addition than the related $\operatorname{Pd}(0)$ complexes. The $\mathrm{Au}$ (III) species that would result from the reaction have in most cases reasonable energies, but the barriers to access them are prohibitively high for moderate temperatures. Oxidative addition is a key step in cross-coupling, and $\mathrm{Au}(\mathrm{I})$ will be thus unable to replace $\operatorname{Pd}(0)$ in most of these reactions. The sluggishness of the reaction in the $\mathrm{Au}(\mathrm{I})$ system seems to be related to its strong preference for coordination 2. This is a specific characteristic of $\mathrm{Au}(\mathrm{I})$ that is not shared by $\operatorname{Pd}(0)$, and explains why, despite having the same number of valence d electrons, these two metals have significantly different reactivity. Our results hint to a possible solution, since the oxidative addition would be much easier when starting from a $[\mathrm{LAu}(\mathrm{I})]^{+}$ complex. Although this type of mono-coordinated complexes are unknown, complexes $\left[\mathrm{LAu}(\mathrm{I}) \mathrm{L}^{\prime}\right]^{+} \mathrm{A}^{-}$with a very weakly coordinated ligand $\mathrm{L}^{\prime}$ might undergo the required oxidative addition reaction under sufficiently mild conditions acting genuine catalysts for cross-coupling reactions of aryl halides. Work towards achieving this goal is in progress.

We thank the MINECO (CTQ2010-16088/BQU, CTQ2011-27033), the AGAUR (2009SGR47, 2009SGR0259), the European Research Council (Advanced Grant No. 321066), and the ICIQ Foundation for the support of this work. We also thank the ICIQ X-Ray Diffraction unit for the X-ray structures.

\section{Notes and references}

1 (a) A. Fürstner and P. W. Davies, Angew. Chem., Int. Ed., 2007, 46, 3410-3449; (b) A. S. K. Hashmi, Chem. Rev., 2007, 107, 3180-3211; (c) E. Jiménez-Núñez and A. M. Echavarren, Chem. Rev., 2008, 108, 3326-3350; (d) D. J. Gorin, B. D. Sherry and F. D. Toste, Chem. Rev., 2008, 108, 3351-3378; (e) V. Michelet, P. Y. Toullec and J.-P. Genêt, Angew. Chem., Int. Ed., 2008, 47, 4268-4315; $(f)$ A. Fürstner, Chem. Soc. Rev., 2009, 38, 3208-3221; $(g)$ C. Aubert, L. Fensterbank, P. Garcia, M. Malacria and A. Simonneau, Chem. Rev., 2011, 111, 1954-1993; (h) M. Rudolph and A. S. K. Hashmi, Chem. Commun., 2011, 47, 6536-6544; (i) C. Obradors and A. M. Echavarren, Chem. Commun., 2015, 50, 16-28; $(j)$ C. Obradors and A. M. Echavarren, Acc. Chem. Res., 2013, DOI: 10.1021/ar400174p.

2 (a) C. González-Arellano, A. Abad, A. Corma, H. Garcia, M. Iglesias and F. Sánchez, Angew. Chem., Int. Ed., 2007, 46, 1536-1538; (b) A. Corma, C. González-Arellano, M. Iglesias, S. Pérez-Ferreras and F. Sánchez, Synlett, 2007, 1771-1774; (c) C. González-Arellano, A. Corma, M. Iglesias and F. Sánchez, Eur. J. Inorg. Chem., 2008, 1107-1115.

3 P. Li, L. Wang, M. Wang and F. You, Eur. J. Org. Chem., 2008, $5946-5951$.

4 O. M. A. de Souza, M. S. Bittar, L. V. P. Mendes, C. Michele and F. da Silva, Synlett, 2008, 1777-1780.

5 P. Yao, J. Chem. Res., 2013, 37, 174-176.

6 J. Han, Y. Liu and R. Guo, J. Am. Chem. Soc., 2009, 131, 2060-2061.

7 (a) S. Carrettin, A. Corma, M. Iglesias and F. Sánchez, Appl. Catal., A, 2005, 291, 247-252; (b) C. González-Arellano, A. Corma, M. Iglesias and F. Sánchez, J. Catal., 2006, 238, 497-501; (c) A. Corma, E. Gutiérrez-Puebla, 
M. Iglesias, A. Monge, S. Pérez-Ferreras and F. Sánchez, Adv. Synth. Catal., 2006, 348, 1899-1907; (d) N. Debono, M. Iglesias and F. Sánchez, Adv. Synth. Catal., 2007, 349, 2470-2476.

8 T. Lauterbach, M. Livendahl, A. Rosellón, P. Espinet and A. M. Echavarren, Org. Lett., 2010, 12, 3006-3009.

9 Review on the topic of trace metal impurities in catalysis: I. Thome, A. Nijs and C. Bolm, Chem. Soc. Rev., 2012, 41, 979-987.

10 (a) A. Corma, R. Juárez, M. Boronat, F. Sánchez, M. Iglesias and H. García, Chem. Commun., 2010, 46, 1446-1448; (b) M. Boronat, D. Combita, P. Concepción, A. Corma, H. García, R. Juárez, S. Laursen and J. D. López-Castro, J. Phys. Chem. C, 2012, 116, 24855-24867.

11 M. Stratakis and H. García, Chem. Rev., 2012, 102, 4469-4506.

12 J. Han, Y. Liu and R. Guo, J. Am. Chem. Soc., 2009, 131, 2060-2061. 13 G. Li, D.-E. Jiang, C. Liu, C. Yu and R. Jin, J. Catal., 2013, 306, 177-183.

14 (a) G. Kyriakou, S. K. Beaumont, S. M. Humphrey, C. Antonetti and R. M. Lambert, ChemCatChem, 2010, 2, 1444-1449; (b) V. K. Kanuru, G. Kyriakou, S. K. Beaumont, A. C. Papageorgiou, D. J. Watson and R. M. Lambert, J. Am. Chem. Soc., 2010, 132, 8081-8086; (c) S. K. Beaumont, G. Kyriakou and R. M. Lambert, J. Am. Chem. Soc., 2010, 132, 12246-12248.

15 M. García-Mota, N. Cabello, F. Maseras, A. M. Echavarren, J. PérezRamírez and N. López, ChemPhysChem, 2008, 11, 1624-1629.

16 R. H. Crabtree, Chem. Rev., 2012, 112, 1536-1554.

17 (a) Y. Shi, K. E. Roth, S. D. Ramgren and S. A. Sand, J. Am. Chem. Soc., 2009, 131, 18022-18023; (b) K. E. Roth and S. A. Blum, Organometallics, 2011, 30, 4811-4813; (c) J. J. Hirner, Y. Shi and S. A. Blum, Acc. Chem. Res., 2011, 44, 603-613; (d) Ni-catalysed coupling of organogold complexes: J. Hirner and S. A. Blum, Organometallics, 2011, 30, 1299-1302.

18 (a) A. S. K. Hashmi, C. Lothschütz, R. Döpp, M. Rudolph, T. D. Ramamurthi and F. Rominger, Angew. Chem., Int. Ed., 2009, 48, 8243-8246; (b) A. S. K. Hashmi, R. Döpp, C. Lothschütz, M. Rudolph, D. Riedel and F. Rominger, Adv. Synth. Catal., 2010, 352, 1307-1314; (c) A. S. K. Hashmi, M. Ghanbari, M. Rudolph and F. Rominger, Chem.-Eur. J., 2012, 18, 8113-8119; (d) M. M. Hansmann, M. Pernpointner, R. Döpp and A. S. K. Hashmi, Chem.-Eur. J., 2013, 19, 15290-15303.

19 (a) M. H. Pérez-Temprano, J. A. Casares and P. Espinet, Chem.-Eur. J., 2012, 18, 1864-1884; (b) J. delPozo, J. A. Casares and P. Espinet, Chem. Commun., 2013, 49, 7246-7248; (c) J. delPozo, D. Carrasco, M. H. Pérez-Temprano, M. García-Melchor, R. Álvarez, J. A. Casares and P. Espinet, Angew. Chem., Int. Ed., 2013, 52, 2189-2193.
20 (a) A. S. K. Hashmi, C. Lothschütz, R. Döpp, M. Ackermann, J. D. B. Becker, M. Rudolph, C. Scholz and F. Rominger, Adv. Synth. Catal., 2012, 354, 133-147; (b) See also: P. Nösel, T. Lauterbach, M. Rudolph, F. Rominger and A. S. K. Hashmi, Chem.-Eur. J., 2013, 19, 8634-8641.

21 (a) A. Tamaki and J. K. Kochi, J. Organomet. Chem., 1972, 40, C81-C84; (b) A. Tamaki and J. K. Kochi, J. Chem. Soc., Dalton Trans., 1973, 2620-2626; (c) A. Johnson and R. J. Puddephatt, Inorg. Nucl. Chem. Lett., 1973, 9, 1175-1177; (d) A. Tamaki and J. K. Kochi, J. Organomet. Chem., 1974, 64, 411-425; (e) A. Johnson and R. J. Puddephatt, J. Organomet. Chem., 1975, 85, 115-121.

22 M. T. Johnson, J. M. J. van Rensburg, M. Axelsson, M. S. G. Ahlquist and O. F. Wendt, Chem. Sci., 2011, 2, 2373-2377.

23 A radical mechanism was found in the reaction between [AuMePR ${ }_{3}$ ] and $\mathrm{CF}_{3} \mathrm{I}$ : A. Johnson and R. J. Puddephatt, J. Chem. Soc., Dalton Trans., 1976, 1360-1363.

24 R. E. Bachman, S. A. Bodolosky-Bettis, C. J. Pyle and M. A. Gray, J. Am. Chem. Soc., 2008, 130, 14303-14310.

25 P. Gualco, S. Ladeira, K. Miqueu, A. Amgoune and D. Bourissou, Angew. Chem., Int. Ed., 2011, 50, 8320-8324.

26 P. S. D. Robinson, G. N. Khairallah, G. da Silva, H. Lioe and R. A. J. O'Hair, Angew. Chem., Int. Ed., 2012, 51, 3812-3817.

27 CCDC 891204 (2a), CCDC 891201 (2b), CCDC 891203 (4a), CCDC 964933 (4b), and CCDC 891202 (5).

28 M. T. Reetz, H. Guo, J.-A. Ma, R. Goddard and R. J. Mynott, J. Am. Chem. Soc., 2009, 131, 4136-4142.

29 D. Morales-Morales, R. Redón, Y. Zheng and J. R. Dilwort, Inorg. Chim. Acta, 2002, 39-44.

30 See ESI $\dagger$ for additional details.

31 M. Besora, C. Gourlaouen, B. Yates and F. Maseras, Dalton Trans., 2011, 40, 11089-11094.

32 (a) S. Komiya, T. A. Albright, R. Hoffmann and J. K. Kochi, J. Am. Chem. Soc., 1976, 98, 7255-7265; (b) Reductive elimination of MeI from LAuI2Me: V. J. Scott, J. A. Labinger and J. E. Bercaw, Organometallics, 2010, 29, 4090-4096.

33 M. Besora, A. A. C. Braga, G. Ujaque, F. Maseras and A. Lledós, Theor. Chem. Acc., 2011, 128, 639-646.

34 Although the majority of $\mathrm{Au}(\mathrm{I})$ complexes are two-coordinated, linear 14-electron species, three- and four-coordinated $\mathrm{Au}(\mathrm{I})$ complexes are also known: (a) M. C. Gimeno and A. Laguna, Chem. Rev., 1997, 97, 511-522; (b) V. R. Bojan, E. J. Fernández, A. Laguna, J. M. López-deLuzuriaga, M. Monge, M. E. Olmos, R. C. Puelles and C. Silvestru, Inorg. Chem., 2010, 49, 5530-5541, and references therein. 